\title{
ON \\ Discurso de OUTORGa do TÍtUlo de HonoráRIA NACIONAL - \\ Dra. Angelita Habr-Gama
}

Eu estou realmente muito emocionada, caríssimo e grande amigo Rubens Belfort Jr., a quem agradeço, em nome de toda a Diretoria desta entidade maravilhosa, a Academia Nacional de Medicina. Agradeço muito emocionada ao nosso querido amigo, Eduardo Lopes Pontes, pelas suas palavras carinhosas - somos amigos de longa data. Felicito-o pela sua carreira, Dr. Eduardo Lopes Pontes, por sua enorme contribuição ao aprimoramento e desenvolvimento e conhecimento acerca das doenças inflamatórias intestinais. A sua grandiosidade é incomparável.

Dois líderes, Prof. Belfort e Prof. Eduardo Lopes Pontes, que honra para mim e que emoçáo eu estou sentindo em incorporar essas centenas de privilegiados membros desta digna Academia, que muito tem contribuído para o desenvolvimento científico e cultural do nosso país. O trabalho da Academia Nacional de Medicina tem se mostrado importante, de uma maneira contínua e progressiva.

O simpósio de hoje foi extraordinário e a ideia de sua realização foi uma enorme contribuição para nossa sociedade. Que coisa maravilhosa que foi esse Simpósio. Isso foi um estímulo a todos os jovens, de ambos os sexos, mostrando que nós, de ambos os sexos, homens e mulheres, devemos trabalhar sempre juntos e na mesma posição, lado a lado. Nunca na frente e nunca atrás. Sempre lado a lado. Eu costumo dizer que essa desigualdade foi criada pela Bíblia, pelo Criador, que disse que a mulher nasceu da costela de Adáo. E o senhor concorda plenamente que nossa criação realmente não foi da costela de Adáo. Homens e mulheres são sempre iguais; são amigos. E as mulheres 


\section{$\sim 126 \curvearrowright$

nunca almejaram, como já foi dito hoje aqui, superar os homens. Nós somos iguais, amigos, lado a lado. Nós podemos sempre contribuir para o desenvolvimento da nossa saúde, para o seu aprimoramento.

Receber esse título foi mais uma honra; eu que fui muito afortunada em minha vida. Tive o privilégio de nascer em uma boa família. Tive o privilégio de casar bem; casar com um homem também emancipado, autossuficiente, e trabalhamos juntos nessa associação que foi muito feliz. Tive o privilégio de ter uma família maravilhosa. Tivemos filhos por opção. Nós temos sobrinhos maravilhosos. Temos colaboradores que constituem nossa família. Tive o privilégio de entrar em uma faculdade de medicina excepcional, com professores maravilhosos. Cursei a pós-graduação na Inglaterra e muito aprendi com eles. Estudar, estudar, estudar sempre. O trabalho é indispensável. Isto me disse sempre o Professor Samir, a quem sempre muito admirei: o trabalho é imbatível. Precisamos trabalhar e estudar para galgar as posiçóes, realizar nossos sonhos. Mas nunca sonhei, em minha vida, chegar a um lugar tâo alto. $\mathrm{Na}$ vida, este foi um privilégio tão grande e dou graças às forças divinas, que o me concederam.
Nasci uma veze ressuscitei recentemente. No dia a dia, mais valorizo a vida. Viver é extremamente importante. Que Deus e todas as forças divinas me ajudem a continuar batalhando, para continuar documentando que as escolhas da minha vida foram acertadas. Trabalhar com os doentes, ajudálos, aprender, estudar, representar, dividir o que sabemos... são fatos da minha vida cotidiana que me enchem de felicidade. E ressuscitar me encheu mais ainda de alegria. Eu renovo meus agradecimentos: as palavras faltam, tanto é que me emociono. Muito obrigada Dr. Rubens, Dr. Eduardo Lopes Pontes, à toda a Diretoria da Academia Nacional de Medicina. Muito obrigada 